\title{
REPORT
}

\section{Building an Alliance on the Commons}

\author{
Harini Nagendra * and Rucha Ghate ${ }^{* *}$
}

India is facing several ecological, economic and social challenges related to the management of natural resources. These challenges are interconnected. Collective action on the management of commons can play a pivotal role in addressing such challenges. Well-managed commons such as rivers, tanks, grazing pastures, forests, woodlots and wetlands play an important role in mitigating poverty and distress migration through income generation and livelihood support for hundreds of millions of poor. Collective action can also help us address issues like cooperative management of farms and community restoration of ponds to name a few. In addressing global challenges like climate change, collective action is required at multiple levels. Instead of focusing on this positive role that the commons can play, we largely focus on narratives of the supposed "tragedy of the commons", an idea borrowed from a western narrative popularized by Garret Hardin in the 1960s, which gained much currency in international circles.

We need an alternative narrative that critically discusses the possibilities for commons to thrive and flourish. In that direction, the Foundation for Ecological Security held four consultation meetings over a period of 14 months. The first meeting was held on 16 November 2017 in Anand, Gujarat; the second on 12 December 2017 in New Delhi, the third (in collaboration with Azim Premii University) on 13 and 14 November 2018 in Bangalore, and the fourth from 4 to 7 December 2018, again in Anand. These four meetings helped to collectively bring together over 50 participants, representing different stakeholders like academia, grass root

\footnotetext{
* School of Development, Azim Premji University, Pixel B, PES campus, Hosur Road, Electronic City, Bangalore 560035; harini.nagendra@apu.edu.in. $\triangle$

** Foundation for Ecological Security, Post Box No. 29, Jahangirpura, PO - Gopalpura, Vadod 388370 Hadgud, District Anand; rucha@fes.org.in

Copyright (C) Nagendra and Ghate 2019. Released under Creative Commons AttributionNonCommercial 4.0 International licence (CC BY-NC 4.0) by the author.

Published by Indian Society for Ecological Economics (INSEE), c/o Institute of Economic Growth, University Enclave, North Campus, Delhi 110007.
}

ISSN: 2581-6152 (print); 2581-6101 (web).

DOI: https://doi.org/10.37773/ees.v2i2.82 
workers, donors, bureaucrats, legal experts, NGOs etc. The meetings brought together experience and perspectives from people working in different parts of the country and outside, from a range of types of commons, and different backgrounds and disciplinary perspectives. These conversations provided a rich set of observations and ideas, discussed further in this paper, that can help to galvanise an alliance for the commons in the coming years.

Participants in all four meetings agreed on the need for broadening the research topics to feed into better policy and practice on the commons to address the prevailing challenge of commons in India, especially to reconcile its aspirations towards development and sustainability. At present, commons constitute one of India's most neglected resources. Between 4060 million hectares of village and forest commons is informally used by local communities (constituting de facto commons), but their rights of access, withdrawal and management on most of this area were not legally recognised (i.e. not de jure commons) until recently. Unfortunately, many of the village commons, especially in rocky and grassy areas are often labelled as "wasteland", leaving them open to private capture. The need to restore the commons is immense with equally weighty challenges. Local communities seeking to manage their commons face difficulties ranging from the erasure and fragmentation of local institutions, norms and practices of commons governance, to inadequately staffed and ill-trained local government bodies, and opaque, unapproachable, and difficult policy and regulatory mechanisms.

Some types of commons have achieved more success than others. In response to grassroots movements by adivasi and local communities, forest commons have been handed over to communities under the Forest Rights Act. Civil society groups, local communities and local panchayats have also spurred efforts to restore village tanks across many parts of rural India. Other types of commons such as community pastures and grazing lands, rivers, wetlands, urban and coastal commons have, however, been converted into open access areas. These commons are neither monitored and managed by the state nor are these handed over to local communities. In the absence of clear management onus, they have become open access areas, and are being steadily eroded. Much needs to be done to help communities gain formal recognition over their commons, as well as for strengthening local institutions and knowledge networks that can influence and create impact. The meetings emphasized the need for co-produced research on the commons, that is, through collaborations between academics, local communities and NGOs to see how commons restoration can simultaneously address livelihoods. 
Given this background, many participants expressed the need for an alliance of different groups working on the commons, from practice, policy, advocacy and research angles. Such an alliance, engaging closely with governments and decision makers, is important to shape the national discourse on commons. This can contribute to strategic policy development and influence action on the ground.

For a greater strategic impact, participants identified three areas - forest, pasture and water commons - where such an alliance could focus, to begin with.. At the same time, the Foundation recommended engagement on other equally important but neglected commons such as community radio and internet, cultural and knowledge commons, genetic resources, urban commons, and coastal waters. It also recommended an integrated focus on outcomes, with equal emphasis on ecological, livelihood and equity aspects.

An alliance for the commons could work in different ways. A gap assessment identified a number of important missing pieces, including the lack of shared vocabulary of commons, a comprehensive commons database, inadequate understanding of behavioural motivations, and research on technology as an enabler or barrier for communities. Across all meetings, participants consistently identified important action points. These included developing polycentric institutions with networks of communities, development organisations, civil society and government agencies. The Foundation emphasized the need to plan and commission research to fill knowledge gaps in important areas such as motivation for behavioural change and levers of transformation.

After the 54th round of the National Sample Survey (NSSO, 1999), which collected information on common property resources at the household and village level across the country, there has been no national follow-up study. A carefully designed national survey is necessary to identify major changes in the status of commons, type of dependence and economic and livelihood relevance. One way to do this could be through a participatory collaboration. Participatory databases on commons can integrate technologies such as GIS and remote sensing with field surveys on institutional norms and practices. Such information can also be used to fill gaps in less known areas like urban commons. These are not, of course, separate points for action, but are in fact mutually reinforcing, and must be worked on in parallel.

In addition, participants identified a number of key mainstream government policies and programmes, including MGNREGA, National Rural Livelihood Mission, Green India Mission, REDD+ action plans, and 
programmes to meet Sustainable Development Goals. They felt that the alliance for the commons needs to engage state and national governments to integrate commons issues into their agendas - as well as into enabling laws such as the Biodiversity Act and Forest Rights Act.

The meetings concluded by identifying three broad focal areas for an alliance on the commons. First, a need to build knowledge, by bringing together a suite of knowledge products, behavioural games, tools and decision support systems to support the practice of the commons, and influence institution building. Second, to convene forums to improve exchanges, advance action, enable cross-learnings, federate community groups to increase their collective bargaining power, and celebrate successes. Third, and most important, such an alliance must play the role of a bridge between community actors, advocacy groups, practitioner NGOs, academic institutions, and Governments, to join the dots between science, practice and policy. The need is immense, and the time for action has never been more urgent for collective, synergistic action on the commons.

\section{REFERENCES}

NSSO. 1999. Common Property Resources in India. Results of the NSS 54th Round, January-June 1998, Report No. 452(54/31/4). New Delhi: National Sample Survey Organisation, Department of Statistics and Programme Implementation, Government of India. 